\title{
Effect of Fly Ash as a Source of Silicon and Potassium on the Incidence of Brown Plant Hopper, Green Leaf Hopper and Stem Borer in Rice under Different Abiotic Stress Condition
}

\author{
S. K. Pedda Ghouse Peera ${ }^{1}$, P. Balasubramaniam ${ }^{2}$ and Rubina Khanam ${ }^{3}$ \\ ${ }^{1}$ M.S. Swaminatham School of Agriculture, Centurion University of Technology and \\ Management, Paralakhemundi, Odisha, India \\ ${ }^{2}$ Anbil Dharmalingam Agricultural College and Research Institute, Tiruchirapalli, India \\ ${ }^{3}$ Crop production division, ICAR-National Rice Research Institute, Cuttack, Odisha, India \\ *Corresponding author
}

\section{Keywords \\ fly ash, silica, Brown plant hopper, Green leaf hopper, Stem borer}

\section{Article Info}

Accepted:

18 May 2020

Available Online:

10 June 2020

\section{A B S T R A C T}

Experiments were carried out in two field conditions (induced drought and flood stress) to analyse the effect of fly ash on certain major pests of rice viz., Brown plant hopper, Green leaf hopper, stem borer. The population of these insects were assessed at regular intervals on plants imposed with treatments including fly ash, Silicate Solubilizing Bacteria (SSB), Farm yard manure (FYM), and graded levels of soil test based potassium. The results revealed that the combination of Fly ash, SSB, FYM, with graded level of soil test based potassium significantly reduced the incidence of Brown plant hopper, Green leaf hopper and stem borer as compared to untreated plots. The silicon content was analysed in the leaf blade and leaf sheath cum stem and it was negatively correlated with the insect population. As the age of the plant increased, silicon content proportionately increased in the plants at different growth stages. The main cause for the death of insects due to fly ash application was wearing of mandibles and main feeding organs of insects which resulted in functionless mandibles so that the insects of paddy die without food. Further, the incidence of major insects was negatively correlated with yield. Application of fly ash as a source of silica and potassium with SSB, FYM with STBK reduced the incidence of Brown plant hopper, Green leaf hopper, Stem borer and increased the yield in rice.

\section{Introduction}

Rice is known as $\mathrm{Si}$ accumulator, the plants benefit from $\mathrm{Si}$ nutrition thereby mitigate biotic (pests and diseases) and abiotic stress (drought and flood) in rice. It is estimated that the rice crop producing a grain yield of $5 \mathrm{tha}^{-}$ ${ }^{1}$ will normally remove from soil of 230 to
$470 \mathrm{~kg} \mathrm{Si} \mathrm{ha}{ }^{-1}$. Salim and Saxena (1992) found that at higher levels of silicon, metamorphism of plant hopper to nymphs to adult was reduced and there was a decrease in adult longevity a female fecundity. It has been reported that silicon suppresses insect pests such as the stem borer, brown plant hopper, green leafhopper, white backed plant hopper, 
and non-insect pests such as spider mites (Ma and Takahashi, 2002). Silica content in the plant is reported to play an important role in strengthening the cell walls of the plants and enhances resistance to both pests and diseases in the field (Qin and Tian, 2004). Chandramani et al., (2009) reported that the combination of FYM, biofertilizers, lignite fly ash and neem cake applied in splits reduced gall midge, stem borer and leaf folder and increased the content of $\mathrm{Si}$ and potassium in plants which induced resistance to pests in plants. Hence silicon content in rice plant was found to be negatively correlated with the incidence of brown plant hopper, green leaf hopper, and stem borer.

Fly ash is a major industrial waste in India. It is a by-product of thermal power station where electricity is produced by burning finely powdered coal. In India around 12.21 $\mathrm{Mt}$ of fly ash is produced every year and for storing one tonne of fly ash, $0.35 \mathrm{~m}^{2}$ area is required. This huge quantity of fly ash produced is dumped in ash disposal areas which are posing a great threat to the environment. Fly ash contains 0.2 to 3.0 per cent potassium and $15-60 \% \mathrm{SiO}_{2}$. Silicon and $\mathrm{K}$ are considered most important nutrient elements in conferring resistance to biotic stresses viz. insect pests, nematodes and diseases and abiotic stresses viz. drought, lodging, salinity, water logging, and nutrient imbalances in soil. Potassium is also responsible for improving the quality of produce. In an attempt to effectively solve the disposal problem of the enormous solid industrial waste, some efforts have been made to use it as an amendment to improve soil fertility, reduce pest incidence and increase yield.

\section{Materials and Methods}

Two field experiments were conducted under induced drought and flood condition in split plot design with two replications. The plot size was $5 \times 4 \mathrm{~m}^{2}$ with 4 main plot treatments and 5 sub plot treatments. The main plot treatments, M1 - Control (0 fly ash), M2 - fly ash@25 tha ${ }^{-1}+$ silicate solubilizing bacteria (SSB)@2 kg ha ${ }^{-1}, \mathrm{M}_{3}$ - fly ash@ $25 \mathrm{t} \mathrm{ha}^{-1}+$ Farm yard manure (FYM) @ $12.5 \mathrm{t} \mathrm{ha}^{-1}, \mathrm{M}_{4}$ - fly ash@25 t ha ${ }^{-1}+(\mathrm{SSB}) @ 2 \mathrm{~kg} \mathrm{ha}^{-1}+$ FYM@12.5 t ha ${ }^{-1}$ were followed and subplot treatments were graded level of soil test based Potassium (STBK), $\mathrm{S}_{1}-$ Control, $\mathrm{S}_{2}$ $25 \%$ STBK, $S_{3}-50 \%$ STBK, $S_{4}-75 \%$ STBK, $\mathrm{S}_{5}-100 \%$ STBK.

The fly ash was applied before transplanting followed by incorporation of silicate solubilizing bacteria and farm yard manure. The rice variety BPT 5204 was selected for field experiment. The observations of pests were observed under natural condition. The incidence of major pests viz., brown plant hopper, green leaf hopper, was recorded in 10 hills selected at random in each plots at 15 days interval and stem borers are measured as percentage of dead heart before flowering and percentage of white ear after flowering as below.

Stem borer damage as dead heart/ white ear $(\%)$

$$
=\frac{\text { Number of affected tillers/meter }}{2}
$$

The rice plant samples are randomly selected from each experimental plot and analysed for silicon content in different parts viz., leaf blade, leaf sheath cum stem and ear head at tillering, panicle initiation and flowering stage.

\section{Estimation of silicon in plant samples}

The powdered samples of different parts of rice plant viz., leaf blade, leaf sheath cum 
stem, ear head, were dried in an oven at $70{ }^{\circ} \mathrm{C}$ for 2-3 hrs prior to analysis. A $0.1 \mathrm{~g}$ sample was digested in a mixture of $7 \mathrm{ml}$ of $\mathrm{HNO}_{3}$ (62 per cent), $2 \mathrm{ml}$ of hydrogen peroxide $\left(\mathrm{H}_{2} \mathrm{O}_{2}\right)$ (30 per cent) and $1 \mathrm{ml}$ of hydrofluoric acid (46 per cent) kept in for 10-15 min for pre-digestion.

The samples were digested using microwave digester (Microwave reaction system Antonpaar Multiwave 3000 solv) with following program 500 watt for 17 minutes with a ramp at $10^{\circ} \mathrm{C}$ per minute to reach the temperature of $150{ }^{\circ} \mathrm{C}, 500$ watt for 10 minutes for holding the temperature of $150{ }^{\circ} \mathrm{C}$ and venting for 10 minutes. The digested samples were diluted to $50 \mathrm{ml}$ with $4 \%$ boric acid (Ma et al., 2002).

The Si concentration in the digested solution was determined by transferring $0.1 \mathrm{ml}$ of digested aliquot to a plastic centrifuge tube, added with $3.75 \mathrm{ml}$ of $0.2 \mathrm{~N}$ $\mathrm{HCl}, 0.5 \mathrm{ml}$ of 10 per cent ammonium molybdate and $0.5 \mathrm{ml}$ of 20 per cent tartaric acid and $0.5 \mathrm{ml}$ of reducing agent 1 - amino 2- napthol- 4- sulfonic acid (ANSA) and the volume was made up to $12.5 \mathrm{ml}$ with distilled water and kept it for one hour. After one hour, the absorbance was measured at $600 \mathrm{~nm}$ with a UV- Visible spectrophotometer. Similarly, standards $(0,0.2,0.4,0.8$, and $1.2 \mathrm{ppm})$ were prepared by using $1000 \mathrm{ppm}$, by following the same procedure. The stock standard of silica was obtained from Merk.

The data obtained from field experiments were subjected to statistical scrutiny (Snedecor and Cochran, 1967) and the analysis was carried out in Agres Agdata. Square root transformation was followed for converting the population numbers. The treatment means were compared by Duncan's Multiple Range Test (DMRT) at $\mathrm{p}=0.05$ for their significance (Gomez and Gomez, 1985).

\section{Results and Discussion}

The results on the incidence of important pests due to the application of fly ash + SSB + FYM+ STBK were represented below.

\section{Brown plant hopper (Nilaparvata lugens stal)}

The mean BPH population was low (0.15/ tiller) in the plots treated with fly ash with SSB and FYM with $100 \%$ STBK which was on par with $75 \%$ STBK over control (0.4/ tiller) when compare to other treatments at tillering stage. At panicle initiation stage the plots treated with fly ash with SSB and FYM with $100 \%$ STBK recorded the low mean $\mathrm{BPH}$ population of (0.1/ tiller) over control (0.35/ tiller) which was on par with $75 \%$ STBK. Similarly in flooded condition no BPH population was observed in the plots treated with fly ash with SSB and FYM with STBK over control (0.4/ tiller) when compare to other treatments. At panicle initiation stage the plots treated with fly ash with SSB and FYM with 100, 75, $50 \%$ STBK recorded no BPH population whereas control recorded (0.45/ tiller).

\section{Green leaf hopper (Nephotettix virescens distant)}

The GLH population was observed at tillering, panicle initiation and at flowering stage. The results revealed that the mean GLH population was low ( $0.1 /$ tiller) in the plots treated with fly ash with SSB and FYM with $100 \%$ STBK which was on par with $75,50 \%$ STBK over control $(0.35 /$ tiller $)$ when compare to other treatments at tillering stage. At panicle initiation stage the plots treated with fly ash with SSB and FYM with $100 \%$ STBK recorded the low mean GLH population of $(0.1 /$ tiller $)$ over control (0.4/ tiller) which was on par with 75, $50 \%$ STBK. 
The treatment effect of fly ash with SSB and FYM with $100 \%$ STBK showed per cent reduction of 28.5 per cent at tillering and 25 per cent at panicle initiation stage in drought condition.

\section{Stem borer (Scirpophaga incertulas walker)}

The stem borer incidence was observed at milky stage of rice. In drought condition the control recorded the highest incidence of stem borer $(7.5 \%)$ whereas the plots treated with fly ash with SSB and FYM with $100 \%$ STBK recorded the lowest per cent of $(0.40)$ incidence of stem borer. In flooded condition the plots treated with fly ash with SSB and FYM with $100 \%$ STBK recorded the lowest white ear per cent (0.45) whereas control recorded the highest incidence of 7.6 per cent white ear.

\section{Silicon content in rice}

The results revealed that the application of fly ash increased the silicon content in rice. The mean Si content of 1.84 per cent in leaf sheath cum stem was recorded due to the addition of fly ash with SSB and FYM over control which recorded 1.64 per cent in leaf sheath cum stem in drought condition and in flood condition 1.63 per cent in leaf sheath cum stem was registered by the addition of fly ash with SSB and FYM. The control recorded the lowest content of 1.44 in leaf sheath cum stem. Among the graded levels of STBK, the highest mean silicon content of 1.96 per cent in leaf blade and 1.76 per cent in leaf sheath cum stem was recorded due to the addition of 100 per cent $\mathrm{K}$ over control. At panicle initiation stage, the treatment effect of fly ash with SSB and FYM showed significant difference and recorded the mean $\mathrm{Si}$ content of 2.51 per cent in leaf blade and 1.96 per cent in leaf sheath cum stem over control which recorded 2.27 per cent in leaf blade and 1.77 per cent in leaf sheath cum stem. Among the graded levels of STBK, the highest mean silicon content of 2.40 per cent in leaf blade and 1.88 per cent in leaf sheath cum stem was recorded due to the addition of 100 per cent $\mathrm{K}$.

Table.1 Effect of fly ash with SSB + FYM with soil test based K on incidence of BPH, GLH and Stem borer in different growth stages of rice* under drought stress

\begin{tabular}{|c|c|c|c|c|c|}
\hline \multirow[t]{3}{*}{ Treatments } & \multicolumn{5}{|c|}{ Drought } \\
\hline & \multicolumn{2}{|c|}{ Tillering } & \multicolumn{3}{|c|}{ Panicle initiation } \\
\hline & ВPH & GLH & BPH & GLH & Stem borer \\
\hline Control & $\begin{array}{c}0.4 \\
(0.63)\end{array}$ & $\begin{array}{c}0.35 \\
(0.59)\end{array}$ & $\begin{array}{c}0.45 \\
(0.66)\end{array}$ & $\begin{array}{c}0.4 \\
(0.63)\end{array}$ & $\begin{array}{c}7.5 \\
(2.73)\end{array}$ \\
\hline $\begin{array}{l}\text { FA@25 } \mathrm{t} \mathrm{ha}^{-1}+\mathrm{SSB}+\text { FYM +0 \% } \\
\text { STBK }\end{array}$ & $\begin{array}{c}0.2 \\
(0.447)\end{array}$ & $\begin{array}{c}0.15 \\
(0.38)\end{array}$ & $\begin{array}{c}0.35 \\
(0.59)\end{array}$ & $\begin{array}{c}0.15 \\
(0.45)\end{array}$ & $\begin{array}{c}2.26 \\
(1.50)\end{array}$ \\
\hline $\begin{array}{l}\text { FA@ } 25 \mathrm{t} \mathrm{ha}^{-1}+\mathrm{SSB}+\text { FYM }+25 \% \\
\text { STBK }\end{array}$ & $\begin{array}{c}0.2 \\
(0.447)\end{array}$ & $\begin{array}{c}0.15 \\
(0.38)\end{array}$ & $\begin{array}{c}0.2 \\
(0.447)\end{array}$ & $\begin{array}{c}0.15 \\
(0.45)\end{array}$ & $\begin{array}{c}1.64 \\
(1.28)\end{array}$ \\
\hline $\begin{array}{l}\text { FA@25 t ha }{ }^{-1}+\text { SSB + FYM +50\% } \\
\text { STBK }\end{array}$ & $\begin{array}{c}0.2 \\
(0.447)\end{array}$ & $\begin{array}{c}0.1 \\
(0.22)\end{array}$ & $\begin{array}{c}0.15 \\
(0.381)\end{array}$ & $\begin{array}{c}0.1 \\
(0.45)\end{array}$ & $\begin{array}{c}1.10 \\
(1.04)\end{array}$ \\
\hline $\begin{array}{l}\text { FA@25 } \mathrm{t} \mathrm{ha}^{-1}+\mathrm{SSB}+\text { FYM +75\% } \\
\text { STBK }\end{array}$ & $\begin{array}{c}0.15 \\
(0.381)\end{array}$ & $\begin{array}{c}0.1 \\
(0.22)\end{array}$ & $\begin{array}{c}0.2 \\
(0.447)\end{array}$ & $\begin{array}{c}0.1 \\
(0.38)\end{array}$ & $\begin{array}{c}1.20 \\
(1.09)\end{array}$ \\
\hline $\begin{array}{l}\text { FA@ } 25 \mathrm{t} \mathrm{ha}^{-1}+\mathrm{SSB}+\mathrm{FYM}+\mathbf{1 0 0 \%} \\
\text { STBK }\end{array}$ & $\begin{array}{c}0.15 \\
(0.381)\end{array}$ & $\begin{array}{c}0.1 \\
(0.22)\end{array}$ & $\begin{array}{c}0.1 \\
(0.316)\end{array}$ & $\begin{array}{c}0.1 \\
(0.32)\end{array}$ & $\begin{array}{c}0.40 \\
(0.62)\end{array}$ \\
\hline SEd & 0.032 & 0.08 & 0.047 & 0.038 & 0.13 \\
\hline $\mathrm{CD}(\mathrm{P}=\mathbf{0 . 0 5})$ & NS & NS & NS & NS & 0.29 \\
\hline
\end{tabular}

*Mean of two replications

@ Values in parentheses are square root transformation 
Table.2 Effect of fly ash with SSB + FYM with soil test based K on incidence of BPH, GLH and Stem borer in different growth stages of rice* under flood stress

\begin{tabular}{|c|c|c|c|c|c|}
\hline \multirow[t]{3}{*}{ Treatments } & \multicolumn{5}{|c|}{ Drought } \\
\hline & \multicolumn{2}{|c|}{ Tillering } & \multicolumn{3}{|c|}{ Panicle initiation } \\
\hline & BPH & GLH & BPH & GLH & Stem borer \\
\hline Control & $\begin{array}{c}0.4 \\
(0.63)\end{array}$ & $\begin{array}{c}0.3 \\
(0.54)\end{array}$ & $\begin{array}{c}0.45 \\
(0.67)\end{array}$ & $\begin{array}{c}0.4 \\
(0.63)\end{array}$ & $\begin{array}{c}7.6 \\
(2.74)\end{array}$ \\
\hline $\begin{array}{l}\text { FA@25 t ha-1 + SSB + FYM +0 \% } \\
\text { STBK }\end{array}$ & 0 & $\begin{array}{c}0.1 \\
(0.31)\end{array}$ & $\begin{array}{c}0.1 \\
(0.32)\end{array}$ & $\begin{array}{c}0.15 \\
(0.38)\end{array}$ & $\begin{array}{c}2.32 \\
(1.52)\end{array}$ \\
\hline $\begin{array}{l}\text { FA@25 t ha-1 + SSB + FYM +25\% } \\
\text { STBK }\end{array}$ & 0 & $\begin{array}{c}0.1 \\
(0.31)\end{array}$ & $\begin{array}{c}0.1 \\
(0.32)\end{array}$ & $\begin{array}{c}0.1 \\
(0.32)\end{array}$ & $\begin{array}{c}1.63 \\
(1.27)\end{array}$ \\
\hline $\begin{array}{l}\text { FA@25 t ha-1 + SSB + FYM +50\% } \\
\text { STBK }\end{array}$ & 0 & 0 & 0 & $\begin{array}{c}0.1 \\
(0.32)\end{array}$ & $\begin{array}{c}1.1 \\
(1.05)\end{array}$ \\
\hline $\begin{array}{l}\text { FA@25 t ha-1 + SSB + FYM +75\% } \\
\text { STBK }\end{array}$ & 0 & 0 & 0 & 0 & $\begin{array}{c}1.19 \\
(1.09)\end{array}$ \\
\hline $\begin{array}{l}\text { FA@25 t ha-1 + SSB +FYM+100\% } \\
\text { STBK }\end{array}$ & 0 & 0 & 0 & 0 & $\begin{array}{c}0.45 \\
(0.66)\end{array}$ \\
\hline SEd & 0.05 & 0.003 & 0.02 & 0.02 & 0.13 \\
\hline $\mathrm{CD}(\mathrm{P}=0.05)$ & NS & 0.007 & NS & 0.04 & 0.28 \\
\hline
\end{tabular}

*mean of two replications@ @ Values in parentheses are square root transformation

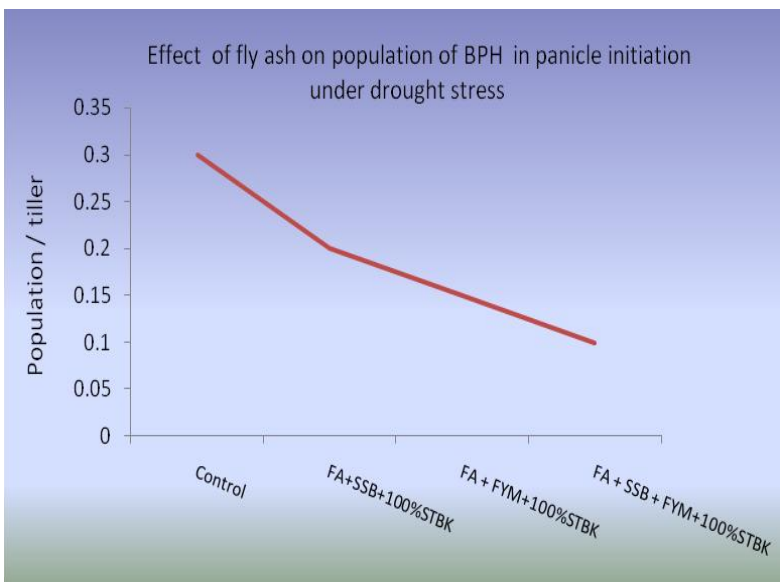

Fig.1a Brown Plant Hopper

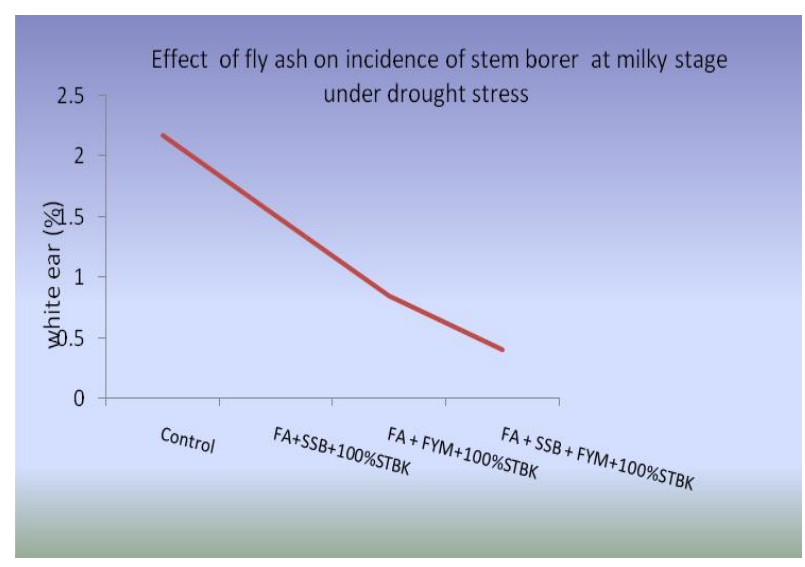

Fig.1c Stem borer

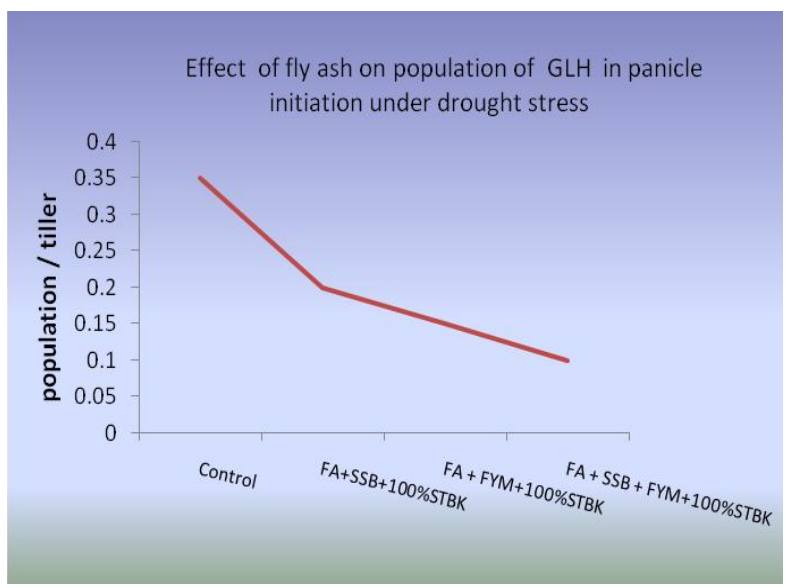

Fig.1b Green leaf Hopper

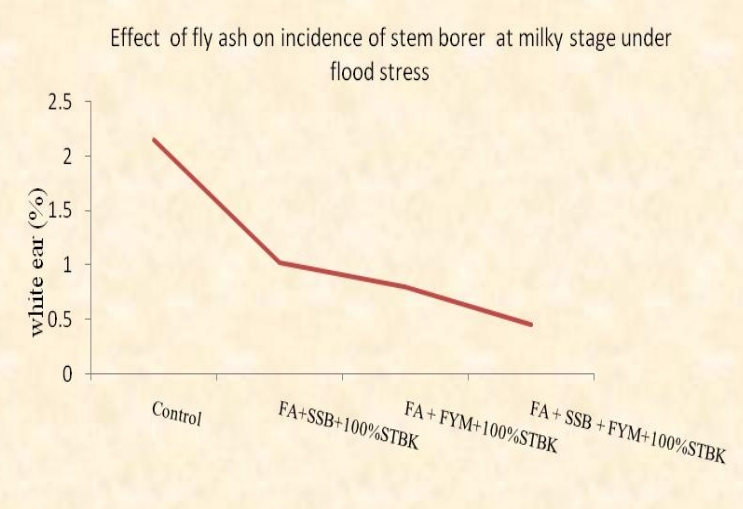

Fig.1d Si content vs stem borer incidence 


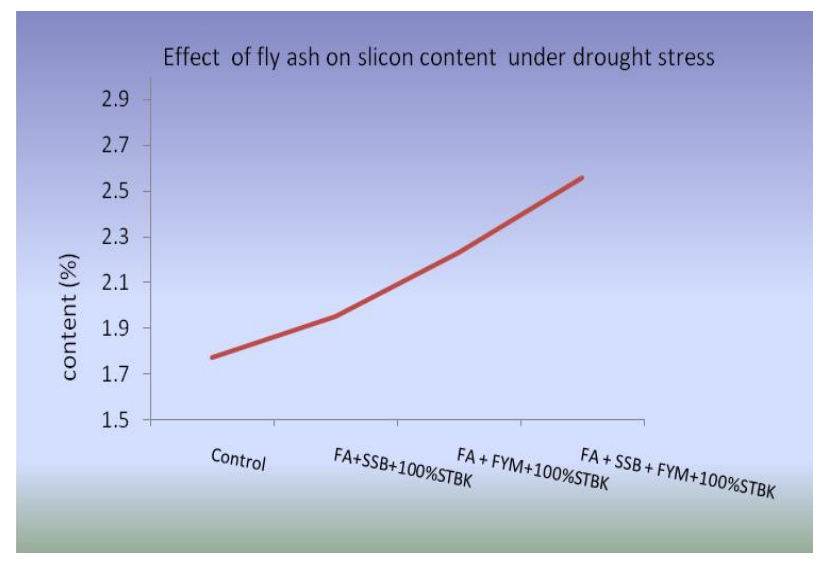

Fig.3 Si content during flood stress

The incidence of brown plant hopper, green leaf hopper, and stem borer in rice were noticed during tillering, panicle initiation and flowering stage respectively. The treatment effect of fly ash with SSB and FYM with 100 $\%$ STBK on incidence of Brown plant hopper showed per cent reduction of 37.5 per cent at tillering and 22.2 per cent at panicle initiation stage in drought condition.

The pest incidence was reduced due to the soluble silicic acid present in the fly ash enhanced the Si uptake in plant which inhibits the feeding activity of BPH and also due to the antibiosis mechanism due to defensive chemicals like phenol (Meyer and Keeping, 2005) The reduction in the incidence of Green leaf hopper (GLH) was due to the addition of fly ash with SSB and FYM with $100 \%$ STBK which significantly reduced the population of GLH by 43.5 and 68.2 per cent under drought and flooded condition respectively. This was due to the fact that as the plant grows older, silica content proportionately increased in the plants and also due to the increase in leaf sheath thickness and epicuticular wax content which results in the inhibition of feeding activity of GLH. The higher levels of silicon and phenolic compounds play important role in the metamorphism of plant hopper to nymphs to adult was reduced and there was a decrease in adult longevity and female fecundity (Rajeshwari, 2000). The results of

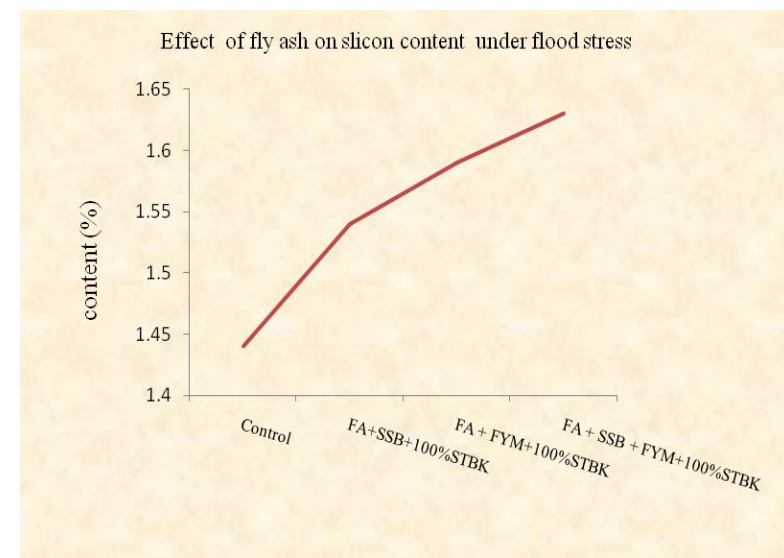

Fig.4 Si content under flood stress

the present study revealed that the combination of fly ash with SSB and FYM with $100 \%$ STBK significantly reduced the incidence of stem borer (46.7\%) at flowering stage compared to control under drought condition whereas, under flooded condition stem borer incidence of 70 per cent at flowering stage was observed. This was due to the application of fly ash that enhances $\mathrm{Si}$ and $\mathrm{K}$ content results in the damage of mandibles of larvae of the rice stem borer.

The results were in consonance with the findings of Djamin and Pathak (1967). Chandramani et al., (2009) reported that the main cause for the death of insects due to fly ash application was wearing of mandibles and main feeding organs of insects which resulted in functionless mandibles so that insect like leaf folder, stem borer die without food.

Hence the application of fly ash with SSB and FYM significantly increased the silicon content at different growth stages and deposition of silicon in the leaf sheath cum stem reduced the incidence of brown plant hopper, green leaf hopper, and stem borer. In conclusion silicon is beneficial to plant growth and helps plants to overcome abiotic and biotic stresses and increasing resistance to pests and diseases, as well as other stresses. 


\section{Acknowledgement}

The authors pay gratitude to Dr. Vimal Kumar Scientist G and Head, Fly Ash Unit and Chairman and members Programme Advisory Committee and Project Monitoring Committee, Department of Science and Technology, Govt. of India for their, critical comments, suggestions and financial assistance during the period of investigation.

\section{References}

Chandramani, P., R.Rajendran, P. Sivasubramanian and C.Muthiah. 2009. Management of hoppers in rice through host nutrition - A novel approach Journal of Biopesticides, 2(1): 99-106.

Djamin, A and M.D. Pathak. 1967. Role of silica in resistance to Asiatic rice borer, Chilo suppressalis (Walker) in rice varieties. Journal of Economic Entomology, 60:347-351.

Ma, J. F and E.

Ma, J.F., S. Goto, K. Tamai and M. Ichii. 2001. Role of root hairs and lateral roots in silicon uptake by rice. Plant Physiology, 127:1773-1780.

Maxwell, F. G., J. N. Jenkins and W. L. Parroot. 1972. Resistance of plants to insects. Advanced Agronomy, 24 : 187265.

Meyer, J.H and M.G. Keeping. 2005. Impact of Silicon in alleviating biotic stress in sugarcane in South Africa. Proc. Int.Soc. Sugar Cane Technol.
Panda, N., B. Pradhan., A. P. Samalo and P. S. P. Rao. 1977. Note on the relationship of some biochemical factors with resistance in rice varieties to yellow borer. Indian J. Agric. Sci., 45 : 499-501.

Qin, Z and S.P. Tian. 2004. Enhancement of biocontrol activity of Cryptococcus laurentii by silicon and the possible mechanism involved. Phytopathology, 95:69-75.

Rajeshwari, R. 2000. Studies on the effect of organic amendments with particular emphasis on lignite fly ash against major pests of rice. M.Sc. (Ag) Thesis, TNAU, Coimbatore.

Salim, M and R.C Saxena .1992. Iron, Silica and Aluminium stresses and varietal resistance in rice: Effects on white backed plant hopper. Crop Sciences, 32: $212-219$.

Subramanian. S and A. Gopalswamy. 1991. Availability of silicon, yield and uptake by rice as influenced by silicate materials with FYM in Madukkur soil Series. Madras Agric. J., 78(5-8): 220222.

Takahashi. 2002. A text book on Soil, fertilizer, and plant silicon research in Japan. Pp. 267.Elsevier, Amsterdam, The Netherlands.

Tayabi, K and P. Azizi. 1984. Influence of silica on rice yield and stem borer (Chilo supremani) in result) Iran in 1979-1980. Pesticides, $18: 20-22$.

\section{How to cite this article:}

Pedda Ghouse Peera. S. K., P. Balasubramaniam and Rubina Khanam. 2020. Effect of Fly Ash as a Source of Silicon and Potassium on the Incidence of Brown Plant Hopper, Green Leaf Hopper and Stem Borer in Rice under Different Abiotic Stress Condition. Int.J.Curr.Microbiol.App.Sci. 9(06): 2243-2249. doi: https://doi.org/10.20546/ijcmas.2020.906.274 